\title{
The reliability of use of WhatsApp in type 1 and type 2 pediatric supracondylar fractures
}

\author{
Tip 1 ve tip 2 pediatrik suprakondiler kııklarda WhatsApp kullanımının güvenilirliği
}

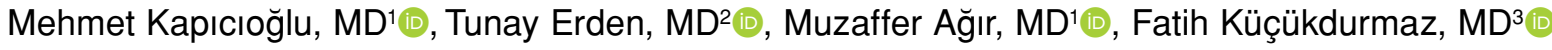 \\ ${ }^{1}$ Department of Orthopedics and Traumatology, Bezmialem Vakif University, Istanbul, Turkey \\ ${ }^{2}$ Department of Orthopedics and Traumatology, Batman State Hospital, Batman, Turkey \\ ${ }^{3}$ Department of Orthopedics and Traumatology, Medicine Faculty of Marmara University, Istanbul, Turkey
}

\begin{abstract}
Objectives: This study aims to evaluate the reliability of the assessment of radiological X-ray images of traumatic injuries in the elbows of children using WhatsApp application, compared to true-size images on a Picture Archiving and Communication System (PACS) screen.
\end{abstract}

Patients and methods: Between November 2017 and March 2018, X-ray images of a total of 90 pediatric patients (53 males, 37 females; mean age 6.2 years; range, 2 to 10 years) with an elbow injury were retrospectively evaluated. The images were captured and sent to three orthopedic surgeons via the WhatsApp instant messaging application on an iPhone $7 \mathrm{~S}$ smartphone. Observers were asked to diagnose and classify for each case over their personal smartphones. The three observers independently assessed the images with a sevenday interval. Following one-week interval, revaluation was conducted using the PACS. Intra- and interobserver reliability were calculated by Cohen Kappa statistics.

Results: There was a good agreement between the first and second evaluations by the physicians via WhatsApp $(\kappa=0.74)$. The intraobserver reliability was very good $(\kappa=0.8)$, moderate $(\kappa=0.55)$, and good $(\kappa=0.67)$. There was no significant difference in the intra- and interobserver reliability between the groups.

Conclusion: Using WhatsApp for consulting is a reliable method which can be used in the emergency setting for decision-making. Using WhatsApp can improve the efficacy of medical assessment and reduce waiting time in emergency admissions, although this method is not a substitution for evaluation of the images using computer-based PACS.

Keywords: Fracture, pediatric elbow, smartphone, supracondylar fracture, WhatsApp.

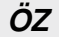

Amaç: Bu çalışmada, çocuklarda travmatik dirsek kırıklarının X-ray görüntülerinin radyolojik değerlendirmesinde WhatsApp uygulamasının güvenilirliği, Görüntü Arşivleme ve İletişim Sistemi (PACS) ekranında gerçek boyutlu görüntüler ile kıyaslanarak değerlendirildi.

Hastalar ve yöntemler: Kasım 2017 - Mart 2018 tarihleri arasında, dirsek travması olan 90 pediatrik hastanın (53 erkek, 37 kadın; ort. yaş 6.2 yıl; dağılım, 2-10 yıl) $\mathrm{X}$-ray görüntüleri retrospektif olarak incelendi. Görüntüler alındıktan sonra iPhone 7S akıllı telefondan WhatsApp anlık mesaj uygulaması ile üç ortopedi uzmanına iletildi. Gözlemcilerden her olgu için kişisel akıllı telefonları üzerinden tanı ve sınıflandırma istendi. Üç gözlemci, görüntüleri yedi gün arayla bağımsız olarak yeniden değerlendirdi. Bir haftalık aralıktan sonra, PACS kullanılarak yeniden değerlendirme yapıldı. Gözlemci içi ve gözlemciler arası güvenilirlik, Cohen Kappa istatistiklerine göre hesaplandı.

Bulgular: Klinisyenler tarafından WhatsApp kullanılarak yapılan birinci ve ikinci değerlendirmeler arasında iyi düzeyde uyum izlendi $(\kappa=0.74)$. Gözlemci içi güvenilirlik çok iyi $(\kappa=0.8)$, orta $(\kappa=0.55)$ ve iyi düzeydeydi $(\kappa=0.67)$. Gruplar arasında gözlemci içi ve gözlemciler arası güvenilirlik açısından anlamlı bir fark bulunamadı.

Sonuç: Acil şartlarda danışma amaçlı WhatsApp kullanımı güvenilir bir yöntemdir. WhatsApp kullanımı acil başvurularda tıbbi değerlendirmenin etkinliğini artırabilir ve bekleme süresini kısaltabilir; ancak, bu yöntem doğrudan bilgisayar tabanlı PACS ile görüntüleri değerlendirmenin yerini alamaz.

Anahtar sözcükler: Kırık, pediatrik dirsek, akıllı telefon, suprakondiler kırık, WhatsApp.

Received: February 13, 2019 Accepted: May 11, 2019 Published online: June 13, 2019

Correspondence: Tünay Erden, MD. Batman Devlet Hastanesi Ortopedi ve Travmatoloji Kliniği, 72070 Batman, Turkey. Tel: +90 554 - 6289045 e-mail: doktorerden@hotmail.com 
Pediatric supracondylar fractures are one of the most common reasons for the admission of children to emergency services, accounting for 15 to $18 \%$ of all emergency service visits, ${ }^{[1-3]}$ and require assessment and treatment immediately, ${ }^{[2,-6]}$ which creates a significant workload and financial burden on the public health system. ${ }^{[5-7]}$ Therefore, some surgeons find the smartphone messaging platforms effective for remote consultation of these patients. However, verbal descriptions without the actual images or reports of these patients are unreliable information for consultation. ${ }^{[4,5]}$ Several studies have demonstrated that the use of smartphones has also reduced the missed diagnosis of fractures in patients in a general practice or a rural hospital and helped to avoid unnecessary trips to a tertiary hospital to show X-rays to a consultant. ${ }^{[8,9]}$ Additionally, this means of communication has helped general practitioners to treat simple dislocations and fractures after consulting orthopedic surgeons and radiologists. ${ }^{[9]}$ Such smartphone applications and their image-viewing functions have been shown to be effective, compared to standard workstation images. ${ }^{[10,11]}$

The smartphone and related technologies have almost become a mandatory part of communication in the today's world. ${ }^{[12,13]}$ The health-related applications of smartphones continue to improve and currently offer very important features which may facilitate patient care. On the other hand, some applications not produced for health-related purposes have become popular among healthcare professionals to facilitate communications related to their daily practice, such as communication related to radiological images, laboratory results, and even clinical pictures. ${ }^{[14-17]}$

The main disadvantages of using smartphones for clinical communication include impaired professional relations, differences in what is considered urgent by physicians and nurses, reduced verbal communication, and unprofessional behavior in some instances. Concerns regarding the use of such applications are mainly related to misdiagnosis, data loss, and patient privacy. ${ }^{[18,19]}$

Among many instant messaging platforms, WhatsApp application (WhatsApp Inc., Mauntain View, California, USA) allegedly offers to provide services to more than 900 million subscribers, which makes WhatsApp the most popular messaging application used globally. ${ }^{[20]}$ In the present study, we aimed to evaluate the reliability of the assessment of radiological X-ray images of supracondylar fractures in children using WhatsApp application, compared to true-size images on a Picture Archiving and Communication System (PACS) screen.

\section{PATIENTS AND METHODS}

This retrospective study included radiological images of pediatric patients between November 2017 and March 2018. A written informed consent was obtained from each parent. The study protocol was approved by the Institutional Review Board. The study was conducted in accordance with the principles of the Declaration of Helsinki.

\section{Study population}

Patients between 2 and 10 years of age who presented to the emergency department for elbow trauma were included. Only distal humeral Gartland type 1 and 2 fractures and soft tissue traumas at the elbow were included in this study. Those with elbow deformities $(n=6)$, previous elbow trauma $(n=15)$, and open elbow injuries $(n=5)$ requiring medical treatment were excluded from the study

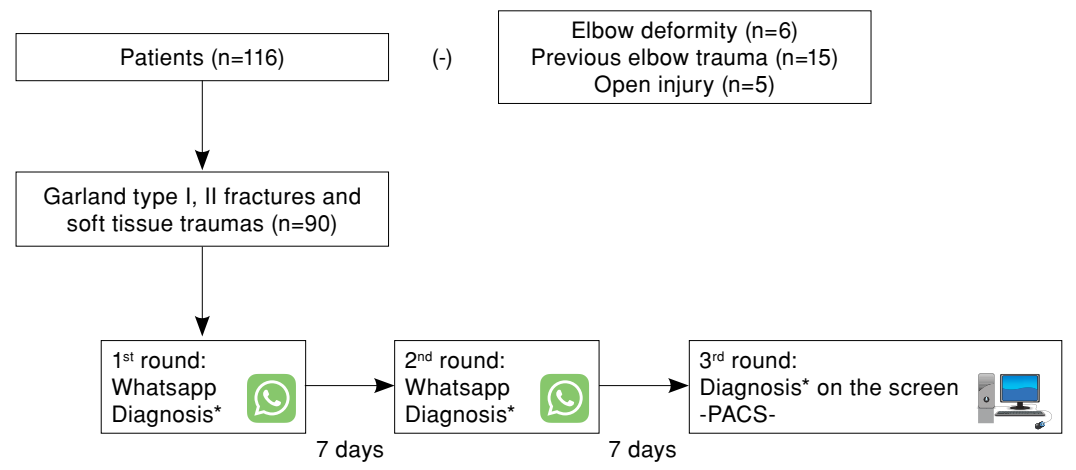

Figure 1. Study design.

* Classification of diagnosis:

Group 1: Soft tissue trauma

Group 2: Gartland type I supracondylar fractures

Group 3: Gartland type II supracondylar fractures 


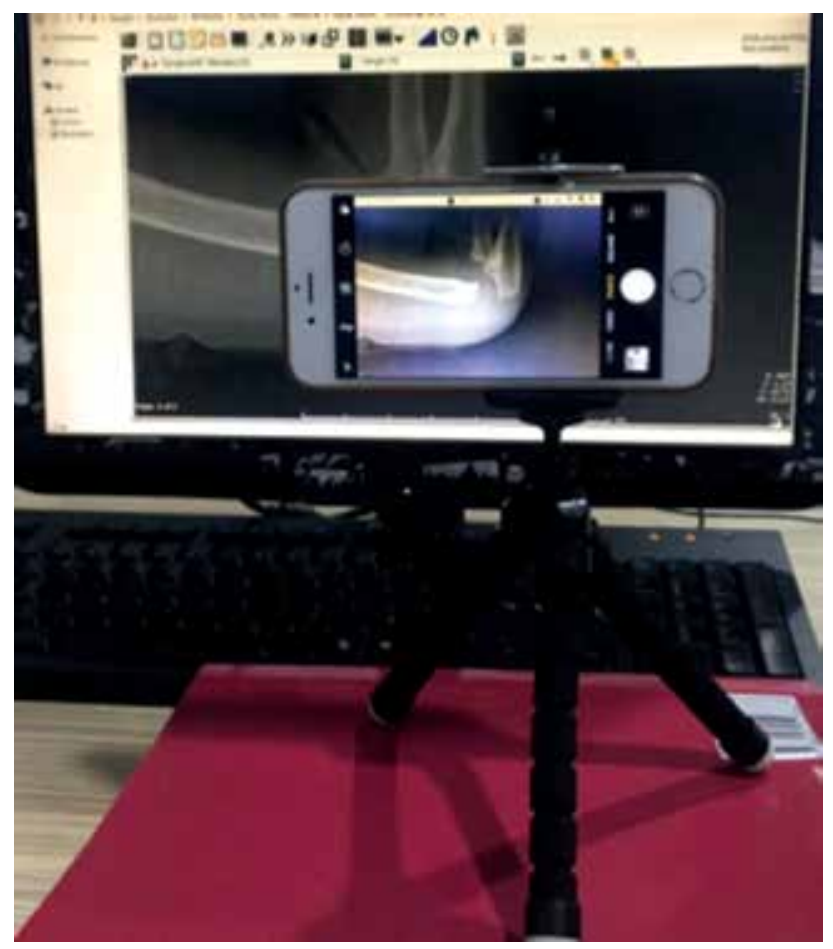

Figure 2. Using an iphone 7S and a tripod.

(Figure 1). Finally, a total of 90 patients (53 males, 37 females; mean age 6.2 years; range, 2 to 10 years) were included. All patients were consulted to three orthopedic surgeons with more than five years of experience in shoulder and elbow surgery sending the lateral radiographs of the elbow via WhatsApp. The consulting surgeon selected one of the three options as the diagnosis: (i) soft tissue trauma, (ii) Gartland type 1 supracondylar fracture, or (iii) Gartland type 2 supracondylar fracture. The second-round consultation was conducted seven days later with the same orthopedic surgeons and the same radiographs, but in a different order. In the final round, the same radiographs were evaluated by the same surgeons on the screen of the PACS workstation, as in routine practice. All radiographs were evaluated by three other blind surgeons on the screen of the PACS workstation, and their consensus was accepted as the gold-standard diagnosis.

TABLE I

Gold standard diagnosis of patients

\begin{tabular}{lcc}
\hline & $\mathrm{n}$ & $\%$ \\
\hline Group 1: Soft tissue injury & 34 & 37.8 \\
Group 2: Gartland type 1 fracture & 27 & 30.0 \\
Group 3: Gartland type 2 fracture & 29 & 32.2 \\
\hline
\end{tabular}

\section{Photos}

Lateral X-rays were captured using an iPhone 7S (Apple Inc., Cupertino, CA, USA) smartphone at a $30-\mathrm{cm}$ distance from the monitor screen using a tripod to capture the entire monitor screen (Figure 2). All identifiers on the images were deleted from the photos before radiological assessment. All consultants made their diagnoses via an iPhone with the WhatsApp application (v2.17.323). Consultants were not informed about the patients' charts and did not have any conversations with the orthopedic surgeon over the phone.

\section{Statistical analysis}

Statistical analysis was performed using the IBM SPSS version 20.0 software (IBM Corp, Armonk, NY, USA). Descriptive data were expressed in median (min-max) values or number and frequency. The kappa correlation coefficient $(\kappa)$ was used to indicate intra- and interobserver reliability. According to the kappa correlation, the results were classified as very good, good, and moderate. Observations were compared between the PACS- and mobile application-based diagnoses. A $p$ value of $<0.05$ was considered statistically significant with $95 \%$ confidence interval (CI).

\section{RESULTS}

The gold-standard diagnosis of the patients is shown in Table I. There was a good agreement between the first and second evaluations by the physicians via WhatsApp $(\kappa=0.74)$. There was a very good agreement between the first and third evaluations by the physicians $(\kappa=0.88)$, and there was a good agreement between the second and third evaluations $(\kappa=0.76)$ (Figure 3$)$.

The intraobserver reliability was very good $(\kappa=0.8)$, moderate $(\kappa=0.55)$, and good $(\kappa=0.67)$ (Figure 4 ). The reliability of the first, second and

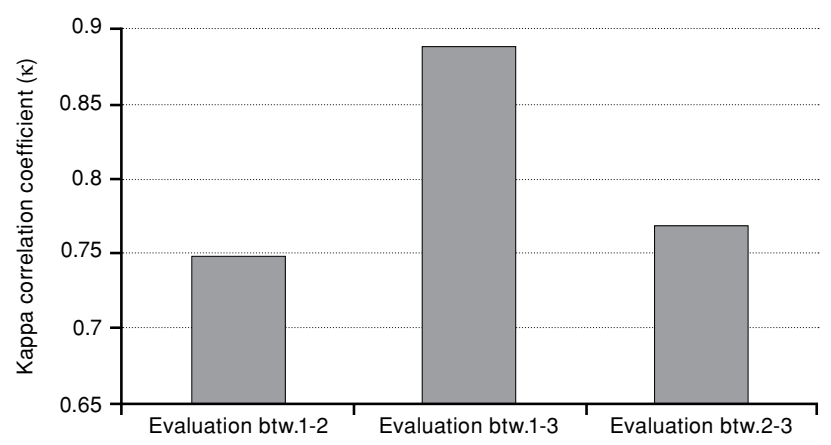

Figure 3. Agreement between first, second and third evaluations. 


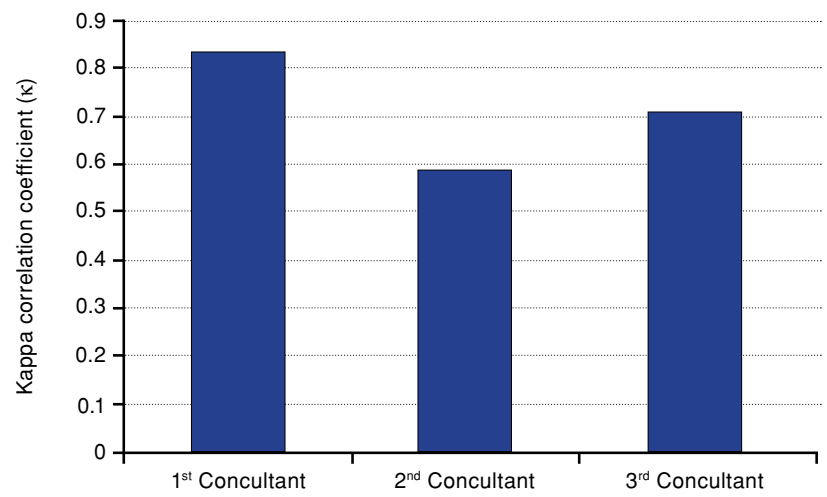

Figure 4. Intraobserver reliability of concultants.

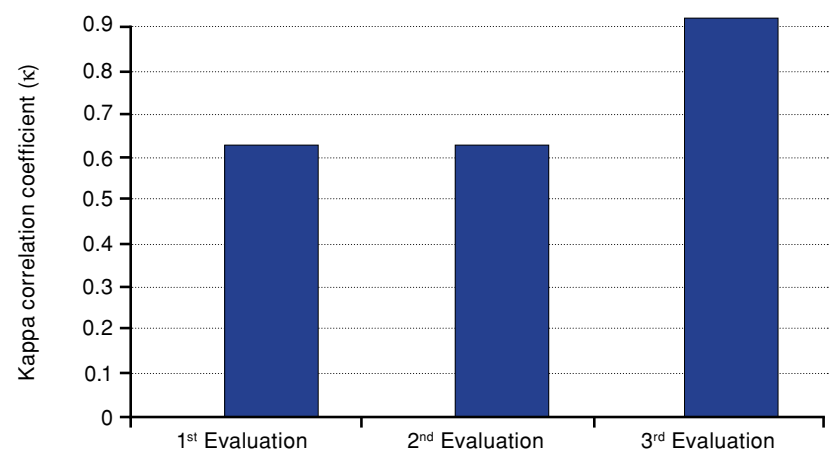

Figure 5. Reliability of evaluations for all concultants.

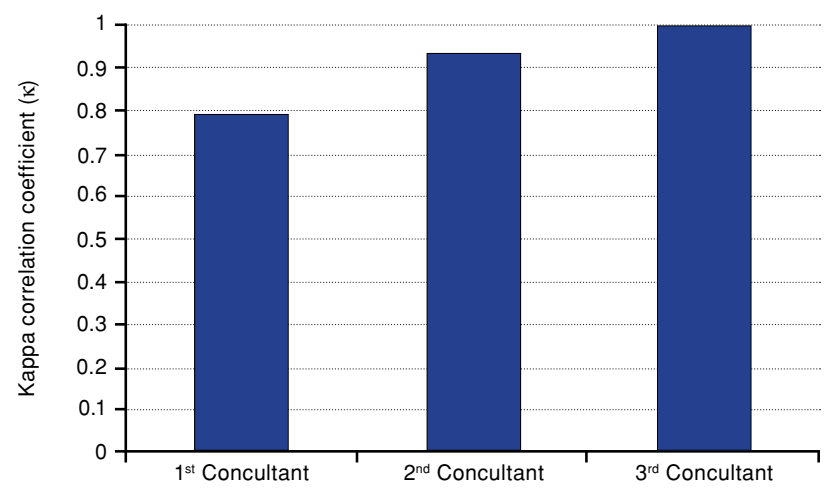

Figure 6. Reliability of concultants with gold standard diagnosis.

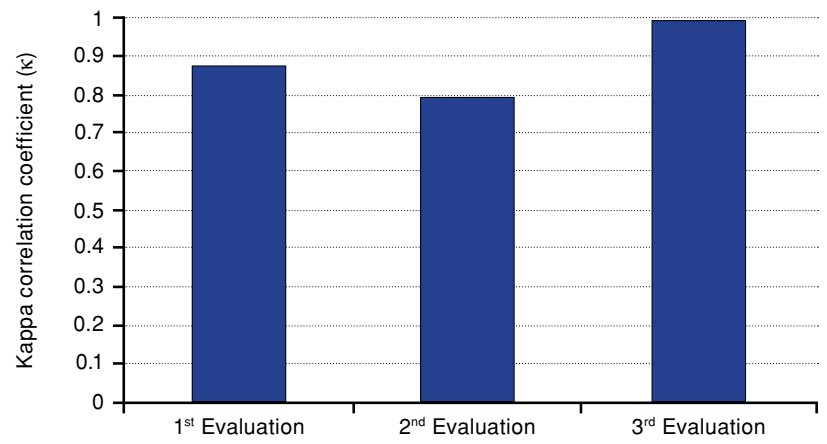

Figure 7. Reliability of evaluations with gold standard diagnosis. third evaluations was moderate $(\kappa=0.55)$, moderate $(\kappa=0.55)$, and very good $(\kappa=0.86)$ for all physicians, respectively (Figure 5). The reliability of the consultants' diagnosis with the gold-standard diagnosis was almost very good for the first consultant $(\kappa=0.78)$, very good for the second consultant $(\kappa=0.92)$, and very good for the third consultant $(\kappa=0.96)$ (Figure 6$)$. The reliability of the median diagnostic value of the first, second, and third evaluations by all consultants with the gold-standard diagnosis was very good $(\kappa=0.86)$, almost very good $(\kappa=0.79)$, and very good $(\kappa=0.97)$, respectively (Figure 7 ).

\section{DISCUSSION}

Capturing X-ray images from a computer screen in routine clinical practice and sharing them through WhatsApp has become a means of communication among physicians for the exchange of opinions. Aside from some disadvantages in observing X-ray images on smartphones, such as the use of small screens, there are several other drawbacks, which may hinder precise understanding of the X-rays. The quality and resolution of images on smartphones are obviously inferior to those of the original X-rays, as WhatsApp reduces the image resolution to roughly one-third of the original. However, in addition to the image losing much of the finer details present when viewed on a computer screen, there are no major changes when viewed on a phone screen. A loss of focus or screen reflections may occur while capturing the images. In addition to image magnification, the WhatsApp application is one missing feature of image manipulation, i.e., contrast adjustment, which is a feature available on PACS workstation for the evaluation of X-rays.

In this study, a method was designed to evaluate and compare orthopedic trauma cases using a smartphone application and a standard computer screen. Based on our study results, we conclude that the designed method has good reliability for the classification, diagnosis, and choice of treatment for pediatric Gartland type 1 and 2 supracondylar fractures. These results are also similar to those of previous studies, which evaluated the consistency of this method in a pediatric population, although a true comparison of the results is difficult due to the different study designs. ${ }^{[8,21,22]}$ In the context of pediatric elbow fractures, our results are consistent with previous studies evaluating these fractures, in particular. ${ }^{[23]}$ This study was conducted to evaluate cases based only on X-ray images to aid the pediatric orthopedic surgeon in diagnosing and tailoring the treatment plan for the trauma with a high accuracy. 
Nonetheless, there are some limitations to this study. Due to the nature of intraobserver studies, recall bias is inevitable. We believe this bias can be minimized by the addition of one-week interval between the evaluation of the cases on smartphone and PACS. In addition, although the number of cases per fracture location was relatively small, the overall number of cases was large, compared to similar previous studies, and we made an effort to select a wide variety of injuries from no fractures at all, which are rare or difficult to recognize on plain radiographs. Nevertheless, we found no more disagreement in the clinical diagnosis, when these cases were evaluated using smartphone technology. Our findings indicate that the use of a smartphonebased instant messaging application for sending images of pediatric injuries is accurate and effective for diagnosis, classification, and treatment planning and WhatsApp can be reliably used in the emergency setting for decision-making, can prove to be critical in the expeditious treatment of injuries requiring surgery, and reduce waiting time in the emergency department and unnecessary interfacility transfers for injuries that can be treated conservatively. This practice may also shorten the number of working hours and scale down the relative shortage of on-call pediatric orthopedic surgeons, thus allowing health service cost reductions.

In conclusion, WhatsApp application has increasingly become prevalent in communication between residents or emergency department providers and consultants. This study demonstrates that this commonly used practice can be effective in establishing a diagnosis and directing treatment and also WhatApp is making smartphones a powerful tool for doctors in the emergency department, primary care clinics, or remote medical centers, enabling timely and appropriate treatment for the injured child. However, we do not endorse this method as the sole substitute for the examination and treatment of an injured child in person, in a timely manner, and by an orthopedic specialist.

\section{Declaration of conflicting interests}

The authors declared no conflicts of interest with respect to the authorship and/or publication of this article.

\section{Funding}

The authors received no financial support for the research and/or authorship of this article.

\section{REFERENCES}

1. Naranje SM, Erali RA, Warner WC Jr, Sawyer JR, Kelly DM. Epidemiology of pediatric fractures presenting to emergency departments in the United States. J Pediatr Orthop 2016;36:e45-8.
2. Chan DS, Podeszwa DA, Brown D, Starr AJ. Expanding pediatric orthopaedic trauma volume at a pediatric level 1 trauma hospital. J Pediatr Orthop 2009;29:612-7.

3. Gattu RK, Teshome G, Cai L, Wright C, Lichenstein R. Interhospital pediatric patient transfers-factors influencing rapid disposition after transfer. Pediatr Emerg Care 2014;30:26-30.

4. Smith BG, Kanel JS, Halsey MF, Thometz JG, Rosenfeld SR, Epps HR, et al. Emergency department on-call status for pediatric orthopaedics: a survey of the POSNA membership. J Pediatr Orthop 2015;35:199-202.

5. Wren TA, Chen AY, Wang VJ, Claudius IA, Skaggs DL. Prior treatment of fracture patients in a tertiary pediatric emergency department: informal referrals from other emergency departments. J Pediatr Orthop 2009;29:137-41.

6. Ömeroğlu H. Basic principles of fracture treatment in children. Eklem Hastalik Cerrahisi 2018;29:52-7.

7. Turgut A, Kalenderer Ö, Bozoğlan M, Bacaksız T, Ağuş H. Flexion type supracondylar humerus fractures: 12 year experience of a pediatric orthopedics clinic. Eklem Hastalik Cerrahisi 2015;26:151-7.

8. Naqvi GA, Daly M, Dawood A, Kurkuri A, Kutty S. Smart consultation for musculoskeletal trauma: accuracy of using smart phones for fracture diagnosis. Surgeon 2014;12:32-4.

9. Jacobs JJ, Jacobs JP, van Sonderen E, van der Molen T, Sanderman R. Fracture diagnostics, unnecessary travel and treatment: a comparative study before and after the introduction of teleradiology in a remote general practice. BMC Fam Pract 2015;16:53.

10. Popat R, Mohan AT, Branford OA. Current uses of smartphones and apps in orthopaedic surgery. Br J Hosp Med (Lond) 2013;74:672-6.

11. Zennaro F, Grosso D, Fascetta R, Marini M, Odoni L, Di Carlo V, et al. Teleradiology for remote consultation using iPad improves the use of health system human resources for paediatric fractures: prospective controlled study in a tertiary care hospital in Italy. BMC Health Serv Res 2014;14:327.

12. Free C, Phillips G, Watson L, Galli L, Felix L, Edwards P, et al. The effectiveness of mobile-health technologies to improve health care service delivery processes: a systematic review and meta-analysis. PLoS Med 2013;10:e1001363.

13. Stahl I, Katsman A, Zaidman M, Keshet D, Sigal A, Eidelman M. Reliability of smartphone-based instant messaging application for diagnosis, classification, and decision-making in pediatric orthopedic trauma. Pediatr Emerg Care 2019;35:403-6.

14. Wani SA, Rabah SM, Alfadil S, Dewanjee N, Najmi Y. Efficacy of communication amongst staff members at plastic and reconstructive surgery section using smartphone and mobile WhatsApp. Indian J Plast Surg 2013;46:502-5.

15. Gulacti U, Lok U. Comparison of secure messaging application (WhatsApp) and standard telephone usage for consultations on Length of Stay in the ED. A prospective randomized controlled study. Appl Clin Inform 2017;8:742-53.

16. Giordano V, Koch H, Godoy-Santos A, Dias Belangero W, Esteves Santos Pires R, Labronici P. WhatsApp messenger as an adjunctive tool for telemedicine: An overview. Interact J Med Res 2017;6:e11.

17. Astarcioglu MA, Sen T, Kilit C, Durmus HI, Gozubuyuk G, Kalcik M, et al. Time-to-reperfusion in STEMI undergoing 
interhospital transfer using smartphone and WhatsApp messenger. Am J Emerg Med 2015;33:1382-4.

18. Charani E, Castro-Sánchez E, Moore LS, Holmes A. Do smartphone applications in healthcare require a governance and legal framework? It depends on the application! BMC Med 2014;12:29.

19. Wu RC, Morra D, Quan S, Lai S, Zanjani S, Abrams H, et al. The use of smartphones for clinical communication on internal medicine wards. J Hosp Med 2010;5:553-9.

20. Johnston MJ, King D, Arora S, Behar N, Athanasiou $\mathrm{T}$, Sevdalis $\mathrm{N}$, et al. Smartphones let surgeons know WhatsApp: an analysis of communication in emergency surgical teams. Am J Surg 2015;209:45-51.
21. Ferrero A, Garavaglia G, Gehri R, Maenza F, Petri GJ, Fusetti C. Analysis of the inter- and intra-observer agreement in radiographic evaluation of wrist fractures using the multimedia messaging service. Hand (N Y) 2011;6:384-9.

22. Taşkesen A, Demirkale İ, Okkaoğlu MC, Özdemir M, Bilgili MG, Altay M. Intraobserver and interobserver reliability assessment of tibial plateau fracture classification systems. Eklem Hastalik Cerrahisi 2017;28:177-81.

23. Paryavi E, Schwartz BS, Meyer CL, Herman MJ, Abzug JM. Reliability and Effectiveness of Smartphone Technology for the Diagnosis and Treatment Planning of Pediatric Elbow Trauma. J Pediatr Orthop 2016;36:483-7. 